Published in:

Journal of the European Economic Association

(MIT Press), 2004, Vol. 2, pp. 289-301

\title{
Welfare Effects of a Monetary Union: The Role of Trade Openness
}

\author{
Robert Kollmann ${ }^{(*)}$ \\ Department of Economics, University of Paris XII \\ 61, Av. du Général de Gaulle; F-94010 Créteil Cedex; France \\ robert_kollmann@yahoo.com
}

Centre for Economic Policy Research, UK

September 3, 2003

\begin{abstract}
This paper evaluates the welfare effects of a monetary union (MU), compared to a floating exchange rate regime, using a quantitative business cycle model of a two-country world with sticky prices. It is assumed that, under a float, there are shocks to the uncovered interest rate parity (UIP) condition. These shocks are shown to have a negative effect on welfare--the detrimental effect is stronger, the higher the degree of trade openness. A MU eliminates UIP shocks, and it may thus raise welfare. The welfare gain from MU is positively linked to openness.
\end{abstract}

JEL classification: E4, F3, F4

Keywords: Exchange rate regime; Welfare; Business cycles; Interest rate parity.

This paper was prepared for the 2003 EEA annual conference. I thank P. Bergin, M. Devereux, C. Erceg, A. Levin and C. Sims for useful discussions/suggestions. 


\section{Introduction}

What are the welfare effects of a monetary union [MU]? This paper addresses that question using a quantitative (calibrated) micro-based business cycle model.

It has long been recognized that a potential key benefit of a MU is the elimination of exchange rate risk, while a "cost" of MU is the loss of monetary policy autonomy. A widely held view is that the (net) benefit from a MU is positively linked to trade openness (McKinnon, 1963). Unfortunately, analyses of these issues have traditionally been based on standard Keynesian sticky-prices models that lack a clear welfare metric.

Recent research has developed theories that are potentially better suited for normative questions: dynamic general equilibrium models of open economies with price stickiness--a literature often referred to as "New Open Economy Macroeconomics", NOEM (see survey by Lane, 2001). However, thus far, normative NOEM studies have used highly stylized (often static) models (that permit to derive closed form solutions) which underpredict sharply the high volatility of exchange rates observed during the post-Bretton Woods era; ${ }^{1}$ this may cast doubts on the relevance of those models for evaluating the welfare effects of a MU (compared to a float).

The paper here assesses welfare using a richer, more realistic quantitative NOEM model of a two-country world. A key feature of the model is that--in contrast to earlier normative NOEM studies--it allows for stationary shocks to the uncovered interest parity (UIP) condition (besides the standard productivity shocks); these "UIP shocks" can be interpreted as reflecting transitory biases in households' exchange rate forecasts. I use an empirical estimate of the time-series process of UIP shocks in the post-Bretton Woods era to calibrate the model. UIP shocks enable the model to generate highly volatile nominal and real exchange rates, under a float. ${ }^{2}$ A MU is assumed to eliminate the UIP shocks (under a MU there is no scope for irrational exchange rate forecasts); a MU may therefore raise welfare.

Model variants with weak trade links between the two countries (1\% imports/GDP ratio) and with strong trade links (20\% trade share) are considered. These variants shed, inter alia, light on optimal monetary arrangements between the US and Europe (weak trade links), and on optimal arrangements among European economies (strong trade). Monetary policy is described by Taylor-style interest rate rules. The parameters of these rules are set at the values that maximize world welfare (the sum of expected household utility in the two countries). A MU is compared to an optimized float.

The model predicts that UIP shocks raise the volatility of consumption and of the real exchange rate, and that they reduce welfare; UIP shocks are more destabilizing for economic activity, and more harmful to welfare, in more open economies--the welfare gain from a MU (due to the elimination of UIP shocks) is thus higher, the greater the degree of openness. The predicted welfare gain from a MU between the US and Europe is very slightly positive--the equivalent of a permanent $0.004 \%$ consumption increase (relative to the float); within Europe, the predicted welfare gain from MU corresponds to a permanent $0.18 \%$ consumption increase.

The analysis here uses Sims' (2000) powerful new numerical technique for solving dynamic models. That method is based on a second-order Taylor approximation of the

\footnotetext{
${ }^{1}$ See, e.g., Bacchetta and van Wincoop, 2000; Benigno and Benigno, 2001; Corsetti and Pesenti, 2001; Devereux and Engel, 2000; Galí and Monacelli, 2000; Obstfeld and Rogoff, 2002; Sutherland, 2002; Tille, 2002.

2 Other features that enhance the realism of the model are physical capital and incomplete international risk sharing. A first step toward normative analysis of a quantitative NOEM model was made by Kollmann (2002), who studied a small open economy. Several recent papers develop quantitative NOEM models, but do not compute welfare (see Kollmann, 2001, for references). With the exception of McCallum and Nelson (1999), who also assume UIP shocks, these models typically underpredict post-Bretton Woods exchange rate volatility. After the research here was completed, I received a paper by Bergin and Tchakarov (2003) that uses quantitative NOEM models to conduct welfare analyses, based on the same numerical technique as the paper here (these authors do not assume UIP shocks and they do not determine welfare maximizing monetary policy rules).
} 
equilibrium conditions (around a steady state). ${ }^{3}$ In contrast to the linear, certainty-equivalent approximations that are widely used in macroeconomics, this approach allows to capture the effect of risk on mean values of endogenous variables; that level effect turns out to be crucial for welfare. Compared to other non-linear techniques, the method here allows to solve models with a large number of state variables--such as the present model.

\section{The model}

There are two countries, "Home" and "Foreign". In each country there are: a household; a central bank; monopolistic competitors that produce a continuum of tradable intermediate goods indexed by $\mathrm{s} \in[0,1]$, using domestic capital and labor (immobile internationally); competitive firms that bundle domestic and imported intermediates into a non-tradable final consumption/investment good. Each household owns the domestic producers and domestic capital (which it rents to firms), and it supplies labor. Markets for rental capital and labor are competitive. Preferences and technologies are symmetric across countries. An asterisk denotes Foreign variables. The following description focuses on the Home country.

\subsection{Final good production}

The Home final good is produced using the aggregate technology

$$
Z_{t}=\left(Q_{t}^{d} / \alpha^{d}\right)^{\alpha^{d}}\left(Q_{t}^{m} / \alpha^{m}\right)^{\alpha^{m}}, \quad \text { with } \alpha^{d}, \alpha^{m}>0 ; \alpha^{d}+\alpha^{m}=1
$$

$Z_{t}$ is date $t$ final good output; $Q_{t}^{d} \quad\left[Q_{t}^{m}\right]$ is a quantity index of domestic [imported] intermediates: $Q_{t}^{\mathbf{i}}=\left\{\int_{0}^{1} q_{t}^{\mathbf{i}}(s)^{(v-1) / v} d s\right\}^{v /(v-1)}$ with $v>1$, for $\mathbf{i}=\mathrm{d}, \mathrm{m}$, where $q_{t}^{d}(s)$ and $q_{t}^{m}(s)$ are quantities of the domestic and imported type $s$ intermediates. Let $p_{t}^{d}(s)$ and $p_{t}^{m}(s)$ be the Home currency prices of these good. Cost minimization in final good production implies:

$q_{t}^{\mathbf{i}}(s)=\left(p_{t}^{\mathbf{i}}(s) / P_{t}^{\mathbf{i}}\right)^{-v} Q_{t}^{\mathbf{i}} ; \quad Q_{t}^{\mathbf{i}}=\alpha^{\mathbf{i}} P_{t} Z_{t} / P_{t}^{\mathbf{i}} \quad(\mathbf{i}=\mathrm{d}, \mathrm{m})$, with $\quad P_{t}^{\mathbf{i}}=\left\{\int_{0}^{1} p_{t}^{\mathbf{i}}(s)^{1-v} d s\right\}^{1 /(1-v)} ; \quad P_{t}=\left(P_{t}^{d}\right)^{\alpha^{d}}\left(P_{t}^{m}\right)^{\alpha^{m}}$. $P_{t}^{d}\left[P_{t}^{m}\right]$ is a price index for domestic [imported] intermediate goods sold in the Home market. Perfect competition implies that the Home final good price is $P_{t}$ (its marginal cost).

\subsection{Intermediate goods producers}

The technology of the firm that produces intermediate good s, in the Home country, is:

$$
y_{t}(s)=\theta_{t}\left(K_{t}(s)\right)^{\psi}\left(L_{t}(s)\right)^{1-\psi}, \quad 0<\psi<1 .
$$

$y_{t}(s)$ is the firm's output; $\theta_{t}$ is an exogenous productivity parameter (identical for all Home intermediates' producers); $K_{t}(s)\left[L_{t}(s)\right]$ is the capital [labor] used by the firm. Its marginal cost is: $M C_{t}=\left(1 / \theta_{t}\right) R_{t}^{\psi /} W_{t}^{1-\psi} \psi^{-\psi}(1-\psi)^{\psi-1}$, where $R_{t}\left[W_{t}\right]$ is the rental rate of capital [wage rate]. The firm's good is sold domestically and exported: $y_{t}(s)=q_{t}^{d}(s)+q_{t}^{m *}(s)$, where $q_{t}^{d}(s) \quad\left[q_{t}^{m *}(s)\right]$ is domestic [export] demand. Its profit is: $\pi_{t}(s)=\left(p_{t}^{d}(s)-M C_{t}\right) q_{t}^{d}(s)+\left(e_{t} p_{t}^{m *}(s)-M C_{t}\right) q_{t}^{m *}(s)$, where $e_{t}$ is the nominal exchange rate (Home currency price of Foreign currency).

Intermediate goods firms set prices in buyer currency. They price discriminate between domestic and export markets, and maximize the value of their profit stream, subject to a restriction on price adjustment (à la Calvo, 1983): these firms cannot change prices (in buyer currency) unless they receive a random "price-change" signal. The probability of receiving this signal in any particular period is $1-d$, a constant. Firms are assumed to meet all demand at posted prices. (Kollmann, 2003, derives the firms' price setting equations.)

\footnotetext{
${ }^{3}$ Anderson and Levin (2002), Collard and Juillard (2001), Judd and Gaspar (1997), Kim and Kim (2003), SchmittGrohé and Uribe (2001), Sutherland (2002) also develop solution methods based on second-order expansions.
} 


\subsection{The representative household}

The preferences of the Home household are described by

$$
E_{0} \sum_{t=0}^{\infty} \beta^{t} U\left(C_{t}, L_{t}\right) \text {, with } 0<\beta<1 .
$$

$C_{t}\left[L_{t}\right]$ is consumption [labor effort]. $U$ is a utility function given by: $U\left(C_{t}, L_{t}\right)=\ln \left(C_{t}\right)-L_{t}$.

The Home household accumulates Home physical capital, subject to the law of motion

$$
K_{t+1}+\phi\left(K_{t+1}, K_{t}\right)=K_{t}(1-\delta)+I_{t},
$$

where $I_{t}$ is gross investment, $0<\delta<1$ is the depreciation rate of capital, and $\phi$ is an adjustment cost function: $\phi\left(K_{t+1}, K_{t}\right)=\frac{1}{2} \Phi\left\{K_{t+1}-K_{t}\right\}^{2} / K_{t}, \quad \Phi>0$. The household holds nominal one-period Home and Foreign currency bonds. Its budget constraint is:

$$
A_{t+1}+e_{t} B_{t+1}+P_{t}\left(C_{t}+I_{t}+F_{t}\right)=A_{t}\left(1+i_{t-1}\right)+e_{t} B_{t}\left(1+i_{t-1}^{*}\right)+\int_{0}^{1} \pi_{t}(s) d s+R_{t} K_{t}+W_{t} L_{t} .
$$

$A_{t}$ and $B_{t}$ are stocks of Home and Foreign currency bonds that mature in period $t$, while $i_{t-1}$ and $i_{t-1}^{*}$ are the interest rates on these bonds. The Home household bears a real cost (in Home final good units) of holding/issuing Foreign currency bonds, denoted $F_{t}: F_{t}=\frac{1}{2} \gamma \cdot\left(e_{t} B_{t+1} / P_{t}\right)^{2}$, $\gamma>0$. This cost ensures that real bond holdings (and other real variables) are stationary, which allows to solve the model using the Sims (2000) method.

The household chooses a strategy $\left\{A_{t+1}, B_{t+1}, K_{t+1}, C_{t}, L_{t}\right\}_{t=0}^{\infty}$ to maximize (1), subject to constraints (2), (3). The following equations are first-order conditions of this problem:

$$
\begin{gathered}
1=\left(1+i_{t}\right) E_{t}\left\{\rho_{t, t+1}\left(P_{t} / P_{t+1}\right)\right\}, \\
1=\left[1+\gamma\left(e_{t} B_{t+1} / P_{t}\right)\right]^{-1}\left(1+i_{t}^{*}\right) E_{t}\left\{\rho_{t, t+1}\left(P_{t} / P_{t+1}\right)\left(e_{t+1} / e_{t}\right)\right\}, \\
1=E_{t}\left\{\rho_{t, t+1}\left(R_{t+1} / P_{t+1}+1-\delta-\phi_{2, t+1}\right) /\left(1+\phi_{1, t}\right)\right\}, \\
W_{t} / P_{t}=C_{t},
\end{gathered}
$$

where $\rho_{t, t+1}=\beta C_{t} / C_{t+1}, \quad \phi_{1, t}=\partial \phi\left(K_{t+1}, K_{t}\right) / \partial K_{t+1}, \quad \phi_{2, t+1}=\partial \phi\left(K_{t+2}, K_{t+1}\right) / \partial K_{t+1}$.

\subsection{Uncovered interest parity (UIP) shocks}

Taking a (log-)linear approximation of (4) and (5) (around $B_{t+1}=0$ ) yields:

$$
i_{t}-i_{t}^{*} \cong E_{t} \ln \left(e_{t+1} / e_{t}\right)-\gamma\left(B_{t+1} e_{t} / P_{t}\right) \text {. }
$$

Because of bond-holding costs (and 2nd order terms suppressed in this approximation), UIP (i.e. the condition $\left.i_{t}-i_{t}^{*}=E_{t} \ln \left(e_{t+1} / e_{t}\right)\right)$ does not hold here. However, departures from UIP caused by bond-holding costs (and the second order terms) are small, in this model. Given the well-documented strong departures from UIP in the post-Bretton Woods era, between the major currency blocs (Lewis, 1995), I assume that the Home Euler condition for Foreign currency bonds (5) is disturbed by a stationary exogenous random variable, $\varphi_{t}$ ("UIP shock"):

$$
1=\left[1+\gamma\left(e_{t} B_{t+1} / P_{t}\right)\right]^{-1}\left(1+i_{t}^{*}\right) \varphi_{t} E_{t}\left\{\rho_{t, t+1}\left(P_{t} / P_{t+1}\right)\left(e_{t+1} / e_{t}\right)\right\} .
$$

Up to a (log-)linear approximation (around $B_{t+1}=0, \varphi_{t}=1$ ), (4) and (6) imply

$$
i_{t}-i_{t}^{*} \cong E_{t} \ln \left(e_{t+1} / e_{t}\right)-\gamma\left(e_{t} B_{t+1} / P_{t}\right)+\ln \left(\varphi_{t}\right) .
$$

$\varphi_{t}$ can be interpreted as reflecting a bias in the households' date $t$ forecast of the date $t+1$ exchange rate, $e_{t+1} \cdot{ }^{4}$ Home and Foreign households make identical exchange rate forecasts.

\footnotetext{
${ }^{4}$ Assume that household beliefs at $t$ about $e_{t+1}$ are given by a probability density function, $f_{t}^{s}$, that differs from the true pdf, $f_{t}$, by a factor $1 / \varphi_{t}: f_{t}^{s}\left(e_{t+1}, \Omega\right)=f_{t}\left(e_{t+1} / \varphi_{t}, \Omega\right) / \varphi_{t}$, where $\Omega$ is any other random variable. The Home Euler equation for Foreign currency bonds is then given by (6).
} 
The counterpart to (7), for the Foreign household is:

$$
i_{t}-i_{t}^{*} \cong E_{t} \ln \left(e_{t+1} / e_{t}\right)+\gamma A_{t+1}^{*} /\left(e_{t} P_{t}^{*}\right)+\ln \left(\varphi_{t}\right) \text {, }
$$

where $A_{t+1}^{*}$ is the Foreign household's stocks of Home currency bonds (the Foreign bondholding cost is $F_{t}^{*}=\frac{1}{2} \gamma\left(A_{t+1}^{*} /\left(e_{t} P_{t}^{*}\right)\right)^{2}$, in Foreign final good units).

\subsection{Market clearing conditions}

Markets for intermediates clear as intermediate goods firms meet all demand at posted prices. Market clearing in Home final good, labor, and rental capital markets requires: $Z_{t}=C_{t}+I_{t}+F_{t}$, $L_{t}=\int_{0}^{1} L_{t}(s) d s, K_{t}=\int_{0}^{1} K_{t}(s) d s$. Bond market clearing requires: $A_{t}+A_{t}^{*}=0, B_{t}+B_{t}^{*}=0$.

\subsection{Monetary policy rules}

Much recent research has focused on policy rules under which the nominal interest rate is set as a function of inflation and of real GDP (e.g., Taylor, 1999). Here, I also include the exchange rate, $e_{t}$, as an argument in the policy rule; this allows to study whether central banks should respond (directly) to that variable. These Home/Foreign policy rules are considered:

$$
i_{t}=i+\Gamma_{\pi} \widehat{\Pi}_{t}^{d}+\Gamma_{y} \hat{Y}_{t}+\Gamma_{e} \ln \left(e_{t} / e_{t-1}\right), \quad i_{t}^{*}=i+\Gamma_{\pi} \widehat{\Pi}_{t}^{d *}+\Gamma_{y} \widehat{Y}_{t}^{*}-\Gamma_{e} \ln \left(e_{t} / e_{t-1}\right),
$$

with $\widehat{\Pi}_{t}^{d}=\left(\Pi_{t}^{d}-\Pi^{d}\right) / \Pi^{d}, \hat{Y}_{t}=\left(Y_{t}-Y\right) / Y$, where $\Pi_{t}^{d}=P_{t}^{d} / P_{t-1}^{d}$ is the growth factor of the price index of Home produced intermediate goods sold in the Home market (gross Home domestic PPI inflation), and $Y_{t}$ is Home real GDP. $i \quad[Y]$ is the steady state nominal interest rate [GDP]. (Throughout this paper, "steady state" refers to the deterministic steady state.) Steady state values are denoted by variables without time subscripts, and $\hat{x}_{t}=\left(x_{t}-x\right) / x$ is the relative deviation of a variable $x_{t}$ from its steady state value. $\Gamma_{\pi}, \Gamma_{y}, \Gamma_{e}$ are parameters.

Central banks make a commitment to set these parameters at time-invariant values that maximize world welfare, defined as $E\left(U\left(C_{t}, L_{t}\right)\right)+E\left(U\left(C_{t}^{*}, L_{t}^{*}\right)\right) .{ }^{5}$ I consider two exchange rate regimes: a "float" (no constraint on exchange rate movements); and a MU (under which policy parameters are set at the values that maximize world welfare, subject to the constraint that the exchange rate has to be kept constant through time). ${ }^{6}$

\subsection{Welfare measures}

A 2 nd order expansion of the Home utility function (around steady state) gives: $E\left(U\left(C_{t}, L_{t}\right)\right) \cong$ $U(C, L)+E\left(\widehat{C}_{t}\right)-L E\left(\hat{L}_{t}\right)-\frac{1}{2} V\left(\widehat{C}_{t}\right)$, where $V\left(\widehat{C}_{t}\right)$ is the variance of $\hat{C}_{t}$ (for the parameters below, $L=0.74)$. I express Home welfare as the permanent relative change in consumption (compared to steady state), $\zeta$, that yields expected utility $E\left(U\left(C_{t}, L_{t}\right)\right): U((1+\zeta) C, L)=$ $U(C, L)+E\left(\widehat{C}_{t}\right)-L E\left(\hat{L}_{t}\right)-\frac{1}{2} V\left(\widehat{C}_{t}\right) \cdot \zeta$ can be decomposed into components, $\zeta^{m}$ and $\zeta^{\mathrm{v}}$, that reflect

\footnotetext{
${ }^{5}$ Fully optimal policy rules would allow for responses of interest rates to all current and lagged state variables; I focus on "simple" rules (such as (8)) because: simple rules capture well actual central bank behavior; simple rules facilitate policy commitment; computationally, it does not seem feasible to determine fully optimal rules for the complex model here (see Kollmann, 2003). Adding selected right-hand side variables to (8) (own- and foreign country GDP, employment, PPI inflation, CPI inflation, exports/imports inflation) only generates minor welfare gains, compared to (8).

${ }^{6} \mathrm{MU}$ is achieved by picking a "large" value for $\Gamma_{e}$. When $\Gamma_{e} \rightarrow \infty$, the model is asymptotically equivalent to a structure in which the two rules (8) are replaced by these equations: (i) the sum of these rules $i_{t}+i_{t}^{*}=2 i+\Gamma_{\pi}\left(\hat{\Pi}_{t}^{d}+\hat{\Pi}_{t}^{d^{*}}\right)+\Gamma_{y}\left(\hat{Y}_{t}+\hat{Y}_{t}^{*}\right)$; (ii) $e_{t}=e_{t-1}$. The MU results below are based on that structure.
} 
the means of consumption and hours worked, and the variance of consumption, respectively: $U\left(\left(1+\zeta^{m}\right) C, L\right)=U(C, L)+E\left(\widehat{C}_{t}\right)-L E\left(\hat{L}_{t}\right), \quad U\left(\left(1+\zeta^{\mathrm{v}}\right) C, L\right)=U(C, L)-\frac{1}{2} V\left(\widehat{C}_{t}\right) . \quad$ (Note: $\ln (1+\zeta)=$ $\left.E\left(\widehat{C}_{t}\right)-L E\left(\hat{L}_{t}\right)-\frac{1}{2} V\left(\widehat{C}_{t}\right), \ln \left(1+\zeta^{m}\right)=E\left(\widehat{C}_{t}\right)-L E\left(\hat{L}_{t}\right), \ln \left(1+\zeta^{v}\right)=-\frac{1}{2} V\left(\widehat{C}_{t}\right),(1+\zeta)=\left(1+\zeta^{m}\right)\left(1+\zeta^{v}\right).\right)$

\subsection{Solution method and parameters (non-policy)}

The model is solved using Sims' (2000) algorithm/computer code. I numerically maximize world welfare with respect to the monetary policy parameters (attention is restricted to parameter values for which a unique stationary equilibrium exists).

Parameters are symmetric across countries. The effects of the exchange rate regime depend on the steady state imports/GDP ratio, $\alpha^{m}$. In one variant of the model I set $\alpha^{m}=0.01$ ("low-trade" variant); in another variant, $\alpha^{m}=0.2$ ("high-trade" variant). These variants shed, i.a., light on optimal monetary arrangements between the US and Europe, and on optimal arrangements within Europe, respectively. I calibrate the "low-trade" variant to quarterly data for the US and an aggregate of three large EU economies (France, Germany, Italy), "EU3".

I set $\beta=0.99 ; v /(v-1)=1.2 ; \psi=0.24 ; \Phi=8 ; \delta=0.025 ; \Pi^{d}=\Pi^{d *}=1$. The steady state value of the UIP shock is set at $\varphi=1$ : in steady state, exchange rate expectations are unbiased (this entails that steady state bond stocks are zero, $A=B=A^{*}=B^{*}=0$ ). Kollmann (2003) shows that Lane and Milesi-Ferretti's (2001) empirical regressions (that document a negative relation between cross-country interest rate differentials and net foreign asset positions normalized by exports) can be used to calibrate the bond-holding cost parameter at $\gamma=0.0038 / Q^{m *}$, where $Q^{m *}$ are steady state exports.

The average price-change interval, $1 /(1-d)$, is set at 4 quarters $(d=0.75)$, consistent with microeconomic evidence on the frequency of price adjustment (Romer, 2001, p.315).

In both the "high-" and "low-trade" variants, productivity follow this process: ${ }^{7}$

$$
\left[\begin{array}{l}
\ln \left(\theta_{t}\right) \\
\ln \left(\theta_{t}^{*}\right)
\end{array}\right]=\left[\begin{array}{ll}
0.81 & 0.03 \\
0.03 & 0.81
\end{array}\right]\left[\begin{array}{l}
\ln \left(\theta_{t-1}\right) \\
\ln \left(\theta_{t-1}^{*}\right)
\end{array}\right]+\left[\begin{array}{c}
\varepsilon_{t}^{\theta} \\
\varepsilon_{t}^{\theta *}
\end{array}\right],
$$

where $\varepsilon_{t}^{\theta}$ and $\varepsilon_{t}^{\theta *}$ are white noises with standard deviation 0.0059 and cross-correlation 0.18 .

Kollmann (2003) discusses estimates of quarterly US-EU3 UIP shocks (1973-94), and argues that the behavior of these shocks can be captured by the following two-factor model:

$$
\ln \left(\varphi_{t}\right)=a_{t}+\omega_{t}, \quad a_{t}=0.88 a_{t-1}+\eta_{t},
$$

where $\omega_{t}$ and $\eta_{t}$ are independent white noises with standard deviations 0.0220 and 0.0109 , respectively. The "low-trade" (US-EU3) variant of the model with an exchange rate float assumes (10); as discussed below, the UIP shock is assumed to "vanish" $\left(\varphi_{t}=1\right)$, under MU.

During the post-Bretton Woods era, EU countries have used a system of fixed-butadjustable exchange rates (EMS), followed by a currency union (EMU). This paper only considers irrevocable floats and MUs. I assume that, under an intra-EU float, UIP shocks would obey (10)--i.e. (10) is also assumed in the "high -trade" variant (with float).

\footnotetext{
${ }^{7}$ (9) is a "symmetrized" version of a VAR model that I fitted to quarterly US and EU3 TFP (1973-1994). Similar processes fit well the behavior of TFP in a range of industrialized countries (e.g., Kollmann, 1996).
} 


\section{Results}

The Table reports model predictions; results are symmetric across countries, and are thus only shown for the Home country. In the Table, $\Delta e_{t} \equiv e_{t} / e_{t-1}, R E R_{t} \equiv e_{t} P_{t}^{*} / P_{t}$ (real exchange rate).

\subsection{Results for the "low-trade" world, $\boldsymbol{\alpha}^{\mathrm{m}}=\mathbf{0 . 0 1}$ [US vs. Europe]}

Cols. 1-5 report results for the "low-trade" world. Cols. 1-3 pertain to the float. Col. 4 considers the MU. These variants assume sticky prices. Col. 5 considers a flex-prices version.

\subsubsection{Float}

In the "low-trade" world with sticky prices (and simultaneous productivity and UIP shocks), welfare and the optimized policy parameters under the float are: $\zeta=-0.006 \% ; \quad \Gamma_{\pi}=7.9$, $\Gamma_{y}=-0.1, \Gamma_{e}=0.0$ (Col. 1). Optimized policy has an aggressive stance against domestic PPI inflation--notice the high value of $\Gamma_{\pi}$ (the standard deviation of $\Pi_{t}^{d}$ is close to zero: $0.01 \%$ ). In closed economies with staggered price setting, optimal policy fully stabilizes PPI inflation, and implies that the behavior of real variables replicates the flex-prices equilibrium (e.g., Rotemberg and Woodford, 1997). This helps to understand why, in the "low-trade" world (trade share: 1\%), optimized policy has a strict anti-inflation stance, and most predictions (including welfare) are virtually identical across the sticky-and flex-prices versions (compare Cols. 1 and 5). (In the flex-prices economy, the monetary policy rule does not affect real variables--in that economy, I set the policy parameters at the values used in Col. 1.)

With simultaneous productivity shocks and UIP shocks, nominal and real exchange rates are highly volatile (stand. dev. of $\Delta e_{t}, R E R_{t}: 7.45 \%, 12.44 \%$ ) - the model captures the high volatility of the US-EU3 exchange rate during the Bretton Woods era (stand. dev. of linearly detrended log quarterly US-EU3 real exchange rate, 1973-1994: 12.89\%).

Cols. 2 and 3 (where the "low-trade" model is subjected just to productivity shocks, and just to UIP shocks, respectively) show that, under the float, UIP shocks explain $99 \%$ of the variances of $\Delta e_{t}$ and $R E R_{t}$, but less than $1 \%$ of the variances of output and consumption (that are generated by simultaneous productivity and UIP shocks). Unsurprisingly, the wide exchange rate fluctuations triggered by UIP shocks have a minor effect on aggregate activity when the trade share is low. UIP shocks have a negative effect on welfare, but that effect is very small (under the float): $\zeta=-0.009 \%$ when there are just UIP shocks (Col. 3).

\subsubsection{Monetary Union}

If, under MU, there were UIP shocks comparable to those under the float, then welfare would be noticeably lower: $\zeta=-0.460 \%$ (not shown in Table); in response to UIP shocks, monetary policy would have to generate large movements of Home and Foreign interest rates to keep the exchange rate constant; this would make consumption, and inflation highly volatile (and be detrimental for welfare).

However, it seems plausible that a MU eliminates the UIP shocks (under MU there is no scope for irrational exchange rate forecasts)--and the subsequent discussion is based on that assumption. MU (without UIP shocks) generates higher welfare $(\zeta=-0.002 \%$; see Col. 4) than the optimized float with UIP shocks (recall that there $\zeta=-0.006 \%$ ). ${ }^{8}$

According to the model here, a MU between the US and Europe would raise welfare, but that gain would be very small (equivalent to a permanent $0.004 \%$ rise in consumption).

\footnotetext{
${ }^{8}$ Under MU, the optimized $\Gamma_{\pi}, \Gamma_{y}$ parameters are very large $\left(\Gamma_{\pi}=5 e 5\right)$. Welfare is a very "flat" function of $\Gamma_{\pi}, \Gamma_{y}$. Imposing "moderate" bounds on their absolute values (e.g. $\left|\Gamma_{\pi}\right|,\left|\Gamma_{y}\right| \leq 50$ ) does not affect the results.
} 
Like the float, the MU exhibits a great deal of price stability (stand. dev. of $\Pi_{t}^{d}$ : $0.08 \%)$. Under MU, the predicted standard deviation of the real exchange rate $(0.67 \%)$ is markedly lower than under the float $(12.44 \%)$; by contrast, the standard deviation of GDP is roughly similar across exchange rate regimes (1.20\% [1.39\%] under MU [float]), in the "lowtrade" world. Because (in that world) exchange rate volatility has little effect on aggregate output and consumption, the suppression of that volatility hardly affects the volatility of these variables (and welfare). The predictions are consistent with the fact that exchange rate volatility between the major currency blocs was markedly lower during the Bretton Wood (BW) peg than in the post-BW era, while GDP volatility was roughly the same in both periods (e.g., Baxter and Stockman, 1989; Kollmann, 2002).

\subsection{Results for the "high-trade" world, $\alpha^{\mathrm{m}}=\mathbf{0 . 2 0}$ (intra-Europe)}

Cols. 6-10 show results for the "high-trade" world.

\subsubsection{Float}

In the "high-trade" world, under the float, UIP shocks have a markedly more destabilizing effect on macro aggregates (the standard deviation of consumption induced by UIP shocks is roughly 20 times greater than in the "low-trade" world; see Cols. 3, 8), and these shocks are markedly more harmful for welfare: $\zeta=-0.188$ with simultaneous productivity and UIP shocks (Col. 6), as well as when there are just UIP shocks (Col.8) (compared to $\zeta=-0.006 \%$, in the "low-trade" world, with the simultaneous two types of shocks).

The low welfare (with UIP shocks) is mainly accounted for by the "mean-component" of the welfare measure $\left(\zeta^{m}=-0.166 \%\right)$ : mean hours worked (as well as the mean capital stock and mean GDP) exceed their steady state level by about $0.25 \%$ (mean consumption is much less affected). That level effect can be linked to the fact that UIP shocks induce sizable fluctuations of productive inputs, especially of imported intermediate goods (standard deviation of imports, $Q_{t}^{m}$ : approx. 7\%); as final good production functions are concave, larger average quantities of intermediates are used to produce a given average quantity of the final good, when there are UIP shocks (in the "high-trade" variant, mean aggregate inputs of domestic [imported] intermediate goods exceed their steady state value by $0.08 \%[0.31 \%]$ ); this triggers the increase in mean hours worked.

\subsubsection{Monetary union}

In the "high-trade" world, welfare under MU (without UIP shocks) is $\zeta=-0.002 \%$ (see Col. 9)--which represents a noticeable welfare improvement, compared to the float with UIP shocks. The welfare gain from the elimination of UIP shocks (due to MU) mainly reflects a reduction in mean hours worked (by $0.24 \%$, compared to float).

In the "high-trade" world, MU induces a sizable reduction in the variability of macro aggregates, and of the real exchange rate (stand. dev. of consumption: $0.88 \%$, compared to $2.08 \%$ under float). Interestingly, the contribution of reduced consumption volatility to the welfare gain from MU is smaller than that of the fall in mean hours worked (the "variancecomponent" of the welfare measure is $\zeta^{v}=-0.004 \%$, compared to $\zeta^{v}=-0.022 \%$ under float).

Note that the welfare gain from MU is greater in the "high-trade" world than in the "low-trade" world. The intuition for this is simple: because UIP shocks are more destabilizing for real economic activity, and more harmful for welfare, the higher the degree of openness, the benefit from eliminating these shocks (by adopting the MU) is positively linked to openness. Empirically, the likelihood that a country pegs its exchange rate is positively linked to openness (e.g., Edwards, 1996). The model here can rationalize this fact. 


\section{REFERENCES}

Anderson, G., Levin, A., 2002. A User-Friendly, Computationally Efficient Algorithm for NonLinear Rational Expectations Models, Working Paper, Federal Reserve.

Bacchetta, P., van Wincoop, E., 2000. Does Exchange Rate Stability Increase Trade and Welfare? American Economic Review 90, 1093-1109.

Baxter, M., Stockman, A., 1989. Business Cycles and the Exchange Rate Regime, Journal of Monetary Economics 23, 377-400.

Benigno, G. \& P., 2001. Price Stability in Open Economies, Review of Economic Studies (forthcoming).

Bergin, P. and Tchakarov, A., 2003 Does Exchange Rate Risk Matter for Welfare? NBER WP 9900.

Calvo, G., 1983. Staggered Prices in a Utility Maximizing Framework, Journal of Monetary Economics 12, 383-398.

Collard, F., Juillard, M., 2001. Perturbation Methods for Rational Expectations Models, Working Paper, CEPREMAP.

Corsetti, G., Pesenti, P., 2001. International Dimensions of Optimal Monetary Policy, NBER WP 7665.

Devereux, M., Engel, C., 2000. Monetary Policy in the Open Economy Revisited: Price Setting and Exchange Rate Flexibility, Review of Economic Studies (forthcoming).

Edwards, S., 1996. The Determinants of the Choice between Fixed and Flexible Exchange Rate Regimes, NBER WP 5756.

Galí, J., Monacelli, T., 2000. Optimal Monetary Policy and Exchange Rate Volatility in a Small Open Economy, Working Paper, Universitat Pompeu Fabra.

Judd, K., Gaspar, J., 1997. Solving Large-Scale Rational Expectations Models, Macroeconomic Dynamics 1, 45-75.

Kim, J., Kim, S., 2003. Spurious Welfare Reversals in International Business Cycle Models, Journal of International Economics 60, 471-500.

Kollmann, R., 1996. Incomplete Asset Markets and the Cross-Country Consumption Correlation Puzzle, Journal of Economic Dynamics and Control 20, 945-961.

Kollmann, R., 2001. The Exchange Rate in a Dynamic-Optimizing Business Cycle Model with Nominal Rigidities, Journal of International Economics 55, 243-262.

Kollmann, R., 2002. Monetary Policy Rules in the Open Economy: Effects on Welfare and Business Cycles, Journal of Monetary Economics 49, 989-1015.

Kollmann, R., 2003. Monetary Policy Rules in an Interdependent World, CEPR DP 4012.

Lane, P., 2001. The New Open Economy Macroeconomics: a Survey, Journal of International Economics 54, 235-266.

Lane, P., Milesi-Ferretti, G., 2001. Long Term Capital Movements, NBER Macro Annual, 73-116.

Lewis, K., 1995. Puzzles in International Financial Markets, in: Grossman, G., Rogoff, K., eds., Handbook of International Economics, Vol. 3 (Elsevier, Amsterdam), 1913-1971.

McCallum, B., Nelson, E., 1999. Nominal Income Targeting in an Open-Economy Optimizing Model, Journal of Monetary Economics 43, 554-578.

McKinnon, R., 1963. Optimum Currency Areas, American Economic Review 53, 717-725.

Obstfeld, M., Rogoff, K., 2002. Global Implications of Self-Oriented National Monetary Rules, Quarterly Journal of Economics 117, 503-535.

Romer, D., 2001. Advanced Macroeconomics (McGraw Hill, New York).

Rotemberg, J., Woodford, M., 1997. An Optimization-Based Econometric Framework for the Evaluation of Monetary Policy, NBER Macroeconomics Annual 12, 297-346.

Schmitt-Grohé , S., Uribe, M., 2001. Solving Dynamic General Equilibrium Models Using a Second-Order Approximation of the Policy Function, Working Paper, Rutgers University.

Sims, C., 2000. Second order accurate solution of discrete time dynamic equilibrium models, Working Paper, Princeton University. www.princeton.edu/ sims.

Sutherland, A., 2002. A simple second-order solution method for dynamic general equilibrium models, Working Paper, University of St.Andrews.

Taylor, J., 1999. Monetary Policy Rules (University of Chicago Press, Chicago).

Tille, C., 2002. How valuable is exchange rate flexibility? Working Paper, NY Fed. 


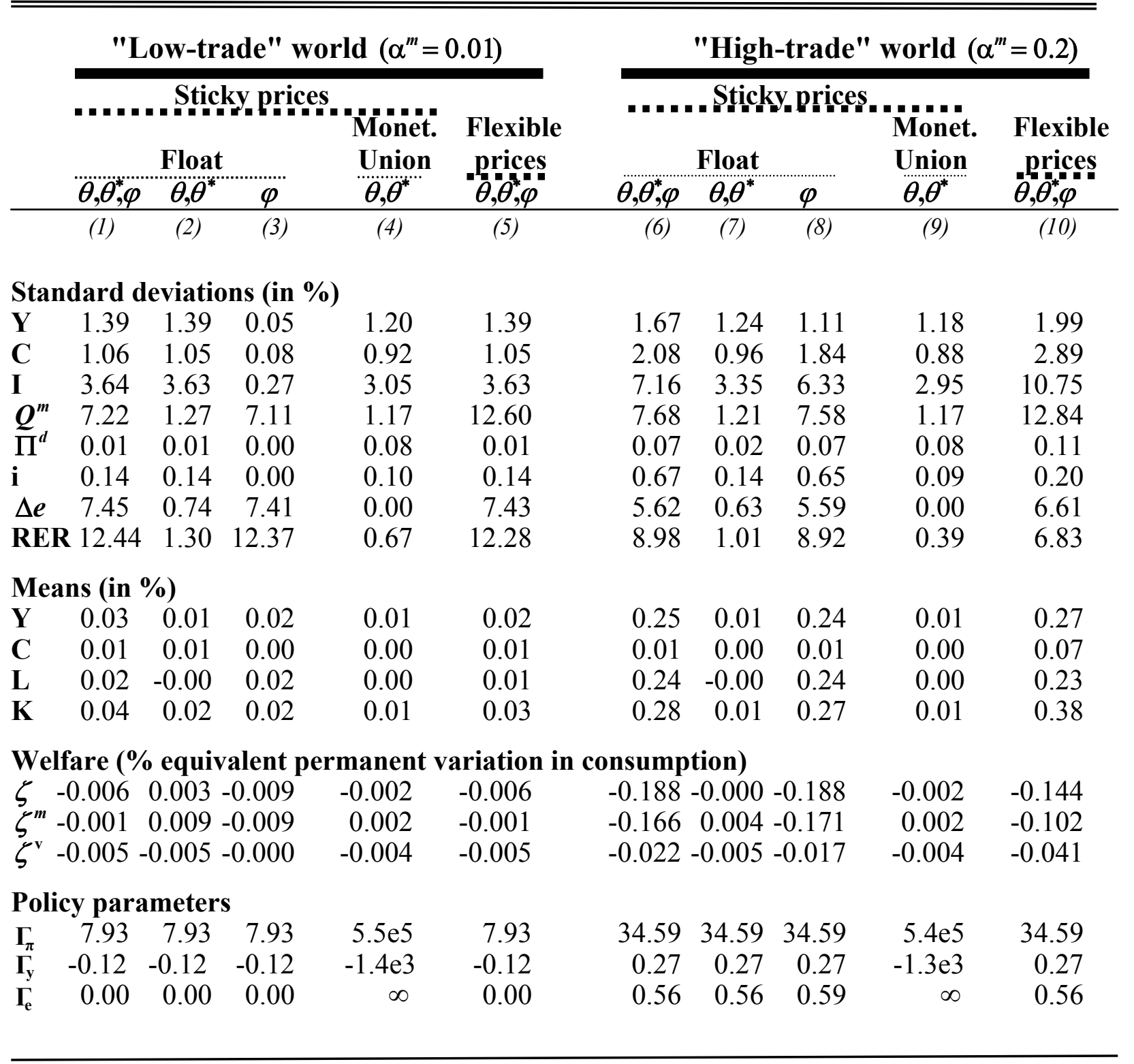

\section{Notes:}

Cols. labeled " $\theta, \theta, \varphi$ " : simulations with simultaneous productivity and UIP shocks; Cols. " $\theta, \theta^{*} "$ : just productivity shocks; Cols. " $\varphi "$ : just UIP shocks. $\varphi$ : UIP shock. $\theta\left[\theta^{*}\right]$ : Home [Foreign] productivity.

Remaining variables pertain to "Home":
$Y \quad: \quad$ GDP.
$C:$ consumption.
$I$ : physical investment.
$\Pi^{d}:$ gross domestic PPI inflation.
$Q^{m}:$ imports.
$i$ : nominal interest rate.
$\Delta e:$ depreciation factor of
$R E R$ : real exchange rate.
$L$ : hours worked.
$K$ : capital stock.
$\zeta, \zeta^{m}, \zeta^{\mathrm{v}}:$ welfare measures.

Moments of $i$ refer to differences from steady state values. Moments of remaining variables: relative deviations from steady state values. All statistics have been expressed in percentage terms. 